\title{
Cytotoxicity and DNA Damage Induced by Magnetic Nanoparticle Silica in L5178Y Cell
}

\author{
Jin Seok Kang ${ }^{1}$, Young Na Yum ${ }^{2}$ and Sue Nie Park ${ }^{2, *}$ \\ ${ }^{1}$ Department of Biomedical Laboratory Science, Namseoul University, Cheonan 330-707, \\ ${ }^{2}$ National Institute of Food and Drug Safety Evaluation, Korea Food and Drug Administration, Cheongwon 365-951, \\ Republic of Korea
}

\begin{abstract}
As recent reports suggest that nanoparticles may penetrate into cell membrane and effect DNA condition, it is necessary to assay possible cytotoxic and genotoxic risk. Three different sizes of magnetic nanoparticle silica $\left(\mathrm{MNP}_{\mathrm{SiO}}\right)(50,100 \mathrm{and} 200 \mathrm{~nm}$ diameter) were tested for cytotoxicity and DNA damage using L5178Y cell. MNP@SiO ${ }_{2}$ had constant physicochemical characteristics confirmed by transmission electron microscope, electron spin resonance spectrometer and inductively coupled plasma-atomic

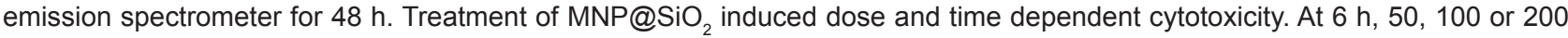
nm MNP@SiO 2 decreased significantly cell viability over the concentration of $125 \mu \mathrm{g} / \mathrm{ml}$ compared to vehicle control $(p<0.05$ or $p<0.01)$. Moreover, at $24 \mathrm{~h}, 50$ or $100 \mathrm{~nm} \mathrm{MNP@SiO}{ }_{2}$ decreased significantly cell viability over the concentration of $125 \mu \mathrm{g} / \mathrm{ml}$ $(p<0.01)$. And treatment of $200 \mathrm{~nm} \mathrm{MNP@SiO}{ }_{2}$ decreased significantly cell viability at the concentration of $62.5 \mu \mathrm{g} / \mathrm{ml}(p<0.05)$ and of $125,250,500 \mu \mathrm{g} / \mathrm{ml}(p<0.01$, respectively). Furthermore, at $48 \mathrm{~h}, 50,100$ or $200 \mathrm{~nm} \mathrm{MNP@SiO}$, decreased significantly cell viability at the concentration of $62.5 \mu \mathrm{g} / \mathrm{ml}(p<0.05)$ and of $125,250,500 \mu \mathrm{g} / \mathrm{ml}(p<0.01$, respectively). Cellular location detected by confocal microscope represented they were existed in cytoplasm, mainly around cell membrane at $2 \mathrm{~h}$ after treatment of MNP@ $\mathrm{SiO}_{2}$. Treatment of $50 \mathrm{~nm} \mathrm{MNP@SiO}$ significantly increased DNA damage at middle and high dose $(p<0.01)$, and treatment of 100 $\mathrm{nm}$ or $200 \mathrm{~nm}$ significantly increased DNA damage in all dose compared to control $(p<0.01)$. Taken together, treatment of MNP@ $\mathrm{SiO}_{2}$ induced cytotoxicity and enhanced DNA damage in L5178Y cell.
\end{abstract}

Key Words: Magnetic nanoparticle silica, Cytotoxicity, Cellular location, Comet assay, DNA damage

\section{INTRODUCTION}

It seems that the safety of nanoparticles and the factors that influence their hazards are not fully understood, even in rapid expansion of nanotechnology. As nanoparticles have commercial potential benefit in market, it is needed to evaluate the possible effects on human and environmental health (Holsapple and Lehman-McKeeman, 2005; Thomas et al., 2006).

It has been reported that nanoparticles might facilitates their uptake into cells and transcytosis across epithelial and endothelial cells into body (Oberdorster et al., 2005), and some nanoparticles could induce undesirable harmful interactions with biological systems and the environment ( $\mathrm{Nel}$ et al., 2006). As smaller size nanoparticles increase reactivity in cells (Thomas and Sayre, 2005) and even more, nanoparticles can bind to DNA or amino acid (Nel et al., 2006), it seems that they are often much more reactive than their bulk material

www.biomolther.org

Open Access DOI: 10.4062/biomolther.2011.19.2.261

pISSN: 1976-9148 elSSN: 2005-4483

Copyright $\odot 2011$ The Korean Society of Applied Pharmacology counterparts. Despite intensive research efforts, it seems that cellular responses to nanoparticles are often inconsistent and even contradictory in some reports.

Actually, it was reported that no significant toxic effects due to silica nanoparticles at the molecular and cellular levels (Jin et al., 2007). However, recent study reported silica nanoparticles were found to induce oxidative stress indicated by induction of reactive oxygen species generation, and membrane lipid peroxidation (Akhtar et al., 2010), and the toxicity were confirmed in recent studies (Nabeshi et al., 2010; Yang et al., 2010; Ye et al., 2010). It seems that these discrepancy of toxicities may be associated with nano characteristics such as size, shape, surface chemistry and degree of aggregation influenced the production of free radicals and oxidative stress (Aillon et al., 2009).

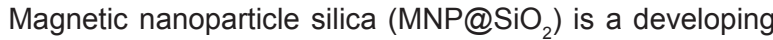
nanoparticle for cell imaging having cobalt-ferrite magnetic

Received Dec 31, 2010 Revised Jan 18, 2011 Accepted Jan 19, 2011

* Corresponding Author

E-mail: suenie@kfda.go.kr

Tel: +82-43-719-4751, Fax: +82-43-719-4750 
core. MNP@SiO ${ }_{2}$ was reported as an agent for specific targeting, cell sorting and bioimaging (Yoon et al., 2005; Yoon et al., 2006). Even magnetic silica nanoparticle can have wide applications in diagnosis, imaging and drug delivery, possible cytotoxicity and genotoxicity are not fully assessed. We set a test chemical as MNP@SiO examined cellular location and DNA damage in L5178Y cell, which has been used in genetic toxicology for mutagenesis and clastogenesis testing.

\section{MATERIALS AND METHODS}

\section{Materials}

Dulbecco's modified Eagle's medium (DMEM), fetal bovine serum (FBS) and penicillin-streptomycin were purchased from Invitrogen (Carlsbad, CA). Methyl methanesulphonate (MMS) was obtained from Sigma (St. Louis, MO).

\section{Cell line, cell culture and nanoparticles treatment}

L5178Y was purchased from American Type Culture Collection (ATCC, Manassas, VA), and was cultured in DMEM medium supplemented with $1.5 \mathrm{~g} / \mathrm{L}$ sodium bicarbonate, $10 \%$
A

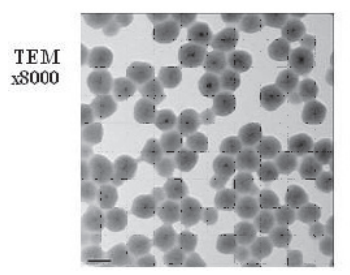

B
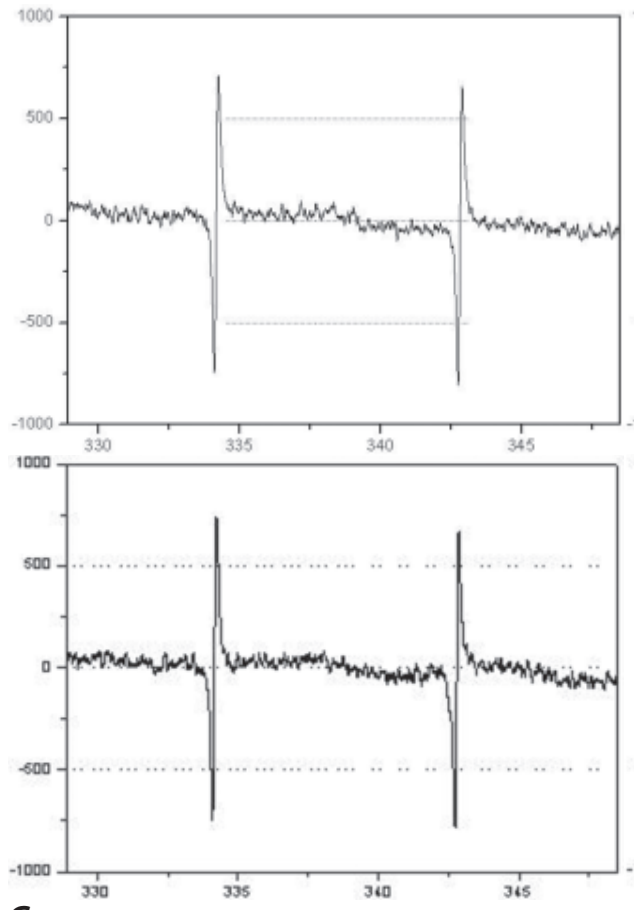

C

\begin{tabular}{cccccc}
\hline Sample & Si $(\mu \mathrm{g} / \mathrm{ml})$ & Co $(\mu \mathrm{g} / \mathrm{ml})$ & $\mathrm{Fe}(\mu \mathrm{g} / \mathrm{ml})$ & $\mathrm{Mn}(\mu \mathrm{g} / \mathrm{ml})$ & $\mathrm{Ni}(\mu \mathrm{g} / \mathrm{ml})$ \\
\hline 50nm-0h & 7.71 & 0.97 & 1.86 & 0.02 & 0.01 \\
$50 \mathrm{~nm}-6 \mathrm{~h}$ & 8.13 & 0.95 & 1.83 & 0.02 & 0.01 \\
$50 \mathrm{~nm}-24 \mathrm{~h}$ & 7.62 & 0.94 & 1.81 & 0.02 & 0.01 \\
$50 \mathrm{~nm}-48 \mathrm{~h}$ & 7.75 & 0.98 & 1.91 & 0.02 & 0.01 \\
\hline
\end{tabular}

$24 \mathrm{~h}$

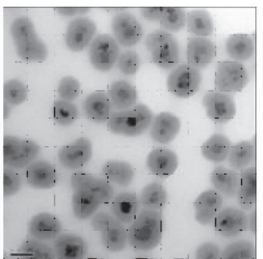

$48 \mathrm{~h}$
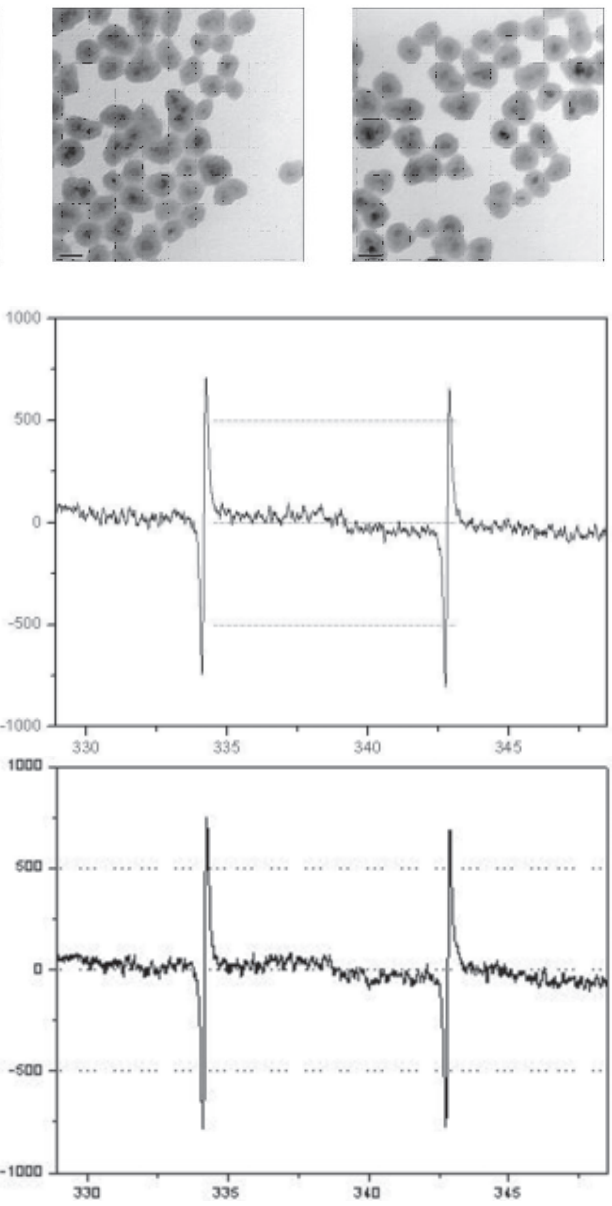

Fig. 1. Characteristics of MNP@ $\mathrm{SiO}_{2}$ analyzed by transmission electron microscope (TEM), electron spin resonance spectrometer (ESR) and inductively coupled plasma-atomic emission spectrometer (ICP-AES). There are no alterations of size of $\mathrm{MNP@SiO}$ during the time points of 6,24 and $48 \mathrm{~h}$ confirmed by TEM (A). And there are no inducing radical or alteration of component of MNP@ $\mathrm{SiO} 2$ during the time points of 6 , 24 and $48 \mathrm{~h}$ by ESR (B) and ICPAES (C). 
FBS and $1 \%$ penicillin at $37^{\circ} \mathrm{C}$ in a $5 \% \mathrm{CO}_{2}$ atmosphere.

\section{Synthesis and chemical characteristics of MNP@SiO}

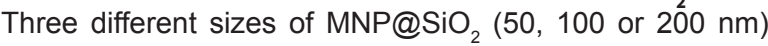
were purchased from Biterials Co. Ltd. Korea. They were prepared by the method as reported previously (Yoon et al., 2005). Analyses of size, component and inducing radical of synthetic MNP@SiO ${ }_{2}$ were carried out from 0 to $48 \mathrm{~h}$ by transmission electron microscope (TEM), inductively coupled plasma-atomic emission spectrometer (ICP-AES) and electron spin resonance spectrometer (ESR), respectively.

\section{Cytotoxicity assay}

Cytotoxicity was assessed by direct cell counting. In brief, L5178Y cells $\left(2 \times 10^{5}\right.$ cells $\left./ \mathrm{ml}\right)$ were treated with three different sizes of $\mathrm{MNP@SiO}$, and were incubated for 6, 24 or $48 \mathrm{~h}$ at the concentration of $0,31.25,62.5,125,250$ and $500 \mu \mathrm{g} / \mathrm{ml}$, and cell counting was carried out.

\section{Cellular location}

Confocal laser scanning microscopy was used to determine the localization of the MNP@SiO . Cellular images captured by confocal mode were segmented into region of interest using high content screening system from 0 to $6 \mathrm{~h}$ after treatment of it using BD Pathway HT (BD Biosciences, San Jose, $\mathrm{CA}, \mathrm{USA}$ ) in manner of real-time imaging.

\section{Comet assay}

Cells $\left(1 \times 10^{5}\right.$ cells $\left./ \mathrm{ml}\right)$ were cultured in 12-well plate were treated with three different sizes of MNP@SiO 2 as low dose
$(31.25 \mu \mathrm{g} / \mathrm{ml})$, middle dose $(62.5 \mu \mathrm{g} / \mathrm{ml})$ and high dose (125 $\mu \mathrm{g} / \mathrm{ml}$ ) for $2 \mathrm{~h}$.

Cells were mixed with LMAgarose, and these mixture was put into Comet Slide ${ }^{\mathrm{TM}}$ (Trevigen, MD) and then into lysis solution for $30-60 \mathrm{~min}$ at $4^{\circ} \mathrm{C}$, alkaline solution for $30-60 \mathrm{~min}$, and were carried out electrophoresis for $30 \mathrm{~min}$, and were dried out after dipping into $70 \%$ alcohol. And then these were stained with ethidium bromide and examined by fluorescene microscope, and were analyzed by Comet assay program (Komet 3.1, Andor Technology, Belfast, UK) to calculate tail moment. MMS (325.75 mg/ml) was used as positive control.

\section{Statistical analysis}

Statistical analyses for cytotoxicity and Comet assay were performed with the Tukey-Kramer method using the JMP program (SAS Institute, Cary, NC). For all comparisons, probability values less than $5 \%(p<0.05)$ were considered to be statistically significant.

\section{RESULTS}

\section{Chemical characteristics of MNP@SiO}

There were no alterations of size of MNP@SiO during the time points of 6,24 and $48 \mathrm{~h}$ confirmed by TEM. And there were no inducing radical or alteration of component of MNP@ $\mathrm{SiO}_{2}$ during the time points of 6,24 and $48 \mathrm{~h}$ by ESR and ICPAES, respectively (Fig. 1).

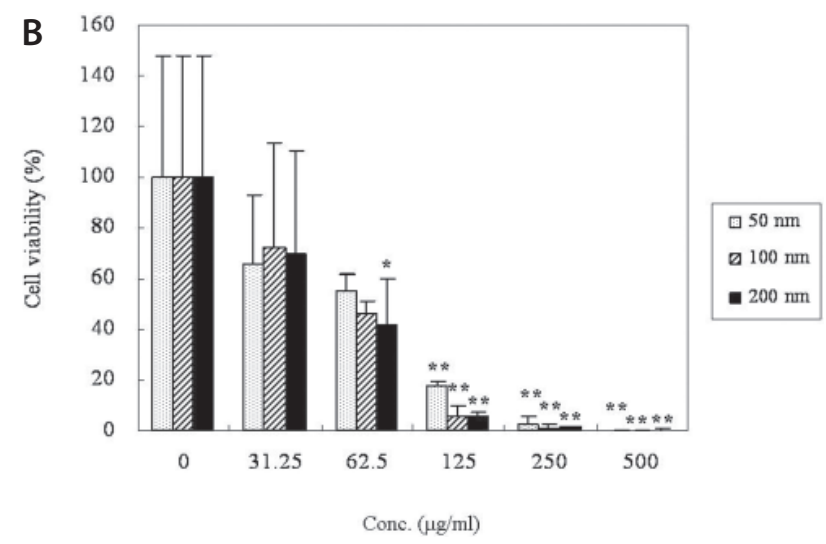

Fig. 2. Cytotoxicity at 6,24 and $48 \mathrm{~h}$ after treatment of 50,100 or 200 nm MNP@ $\mathrm{SiO}_{2}$. L5178Y is cultured in DMEM medium supplemented with $1.5 \mathrm{~g} / \mathrm{L}$ sodium bicarbonate, $10 \% \mathrm{FBS}$ and $1 \%$ penicillin at $37^{\circ} \mathrm{C}$ in a $5 \% \mathrm{CO}_{2}$ atmosphere and cytotoxicity is assessed at following time points. (A) $6 \mathrm{~h}$, (B) $24 \mathrm{~h}$, (C) $48 \mathrm{~h}$. ${ }^{*},{ }^{* *}$ Significantly different from vehicle control $(p<0.05, p<0.01$, respectively). 


\section{Cytotoxicity assay}

Treatment of MNP@SiO ${ }_{2}$ induced dose and time dependent cytotoxicity. At $6 \mathrm{~h}$ after treatment, 50, 100 or $200 \mathrm{~nm}$ $\mathrm{MNP@SiO}{ }_{2}$ decreased significantly cell viability over the concentration of $125 \mu \mathrm{g} / \mathrm{ml}$ compared to vehicle control $(p<0.05$ or $p<0.01$ ) (Fig. 2A).

Moreover, at $24 \mathrm{~h}$ after treatment, 50 or $100 \mathrm{~nm}$ MNP@ $\mathrm{SiO}_{2}$ decreased significantly cell viability over the concentration of $125 \mu \mathrm{g} / \mathrm{ml}$ compared to vehicle control $(p<0.01)$. And treatment of 200 nm MNP@SiO ${ }_{2}$ decreased significantly cell viability at the concentration of $62.5 \mu \mathrm{g} / \mathrm{ml}(p<0.05)$ and of 125 , $250,500 \mu \mathrm{g} / \mathrm{ml}(p<0.01$, respectively) compared to vehicle control (Fig. 2B).

Furthermore, at $48 \mathrm{~h}$ after treatment, 50, 100 or $200 \mathrm{~nm}$ $\mathrm{MNP@SiO}{ }_{2}$ decreased significantly cell viability at the concentration of $62.5 \mu \mathrm{g} / \mathrm{ml}(p<0.05)$ and of $125,250,500 \mu \mathrm{g} / \mathrm{ml}$ $(p<0.01$, respectively) compared to vehicle control (Fig. $2 \mathrm{C})$.

\section{Cellular location}

Cells were treated with three different sizes of MNP@SiO and the cells were fixed with fixatives, and cellular location was detected by confocal microscope. It showed that these nanoparticles were existed in cytoplasm at $2 \mathrm{~h}$ after treat-

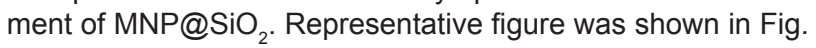

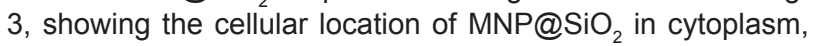
mainly around cell membrane.

\section{Comet assay}

Cell were treated with three different sizes of $\mathrm{MNP@SiO}_{2}$ as low dose $(31.25 \mu \mathrm{g} / \mathrm{ml})$, middle dose $(62.5 \mu \mathrm{g} / \mathrm{ml})$ and high dose $(125 \mu \mathrm{g} / \mathrm{ml})$ for $2 \mathrm{~h}$. Treatment of $50 \mathrm{~nm} \mathrm{MNP@ \textrm {SiO } _ { 2 }}$ significantly increased DNA damage at middle and high dose $(p<0.01)$, and treatment of $100 \mathrm{~nm}$ or $200 \mathrm{~nm} \mathrm{MNP@SiO}$ significantly increased DNA damage in all dose compared to control $(p<0.01)$ (Fig. 4). And treatment of MMS as positive control also significantly increased DNA damage compared to control $(p<0.01)$.

\section{DISCUSSION}

In the present study, treatment of 50,100 or 200 nm MNP@ $\mathrm{SiO}_{2}$ represented cellular toxicity in L5178Y cells. And DNA damage was appeared at the treatment of 50,100 or $200 \mathrm{~nm}$ $\mathrm{MNP@SiO} 2$ by Comet assay.

Treatment of 50, 100 or 200 nm MNP@SiO ${ }_{2}$ induced dose and time dependent cytotoxicity. At 6, 24, $48 \mathrm{~h}$ after treatment, 50,100 or $200 \mathrm{~nm} \mathrm{MNP@SiO}{ }_{2}$ decreased cell viability over the concentration of $62.5 \mu \mathrm{g} / \mathrm{ml}$ compared to vehicle control, and this may be related to entrance of these nanoparticles in cytoplasm. And cellular images captured by confocal mode using high content screening system showed that nanoparticles were moved into cytoplasm within a short time.

It was reported that sizes of nanoparticles were critical determinants of degree of cytotoxicity and potential mechanisms of toxicity (Sohaebuddin et al., 2010) and nanoparticles may be more toxic than micron-sized one, as showing that nanosized cobalt-chromium alloy induced more DNA damage than micron-sized particles (Papageorgiou et al., 2007) and the ultrafine particles elicited a persistently high inflammatory reaction in the lungs of the animals compared to the larger-sized particles (Oberdorster et al., 1994). However, in this study, MNP@SiO ${ }_{2}$ did not show this tendency and 200 nm size of silica nanoparticles also induced cytotoxicity. As confocal microscope findings showed that MNP@SiO ${ }_{2}$ could enter the cell after treatment, irrespective of size, it may be owing to early cellular entry of $\mathrm{MNP} @ \mathrm{SiO}_{2}$. Base on recent reports that toxicity of silica nanoparticles was mediated through oxidant generation (Akhtar et al., 2010), and treatment of silica nanoparticles induced inflammation (Hamilton et al., 2008) and enhanced inflammatory cytokines (Nishimori et al., 2009), they could induce cellular toxicity even in larger size as well as small size.

In this study, we do not exclude the possibility they can enter the nuclei. Recent report illustrated that carbon nanotubes were seen to enter the cytoplasm and localize within the cell
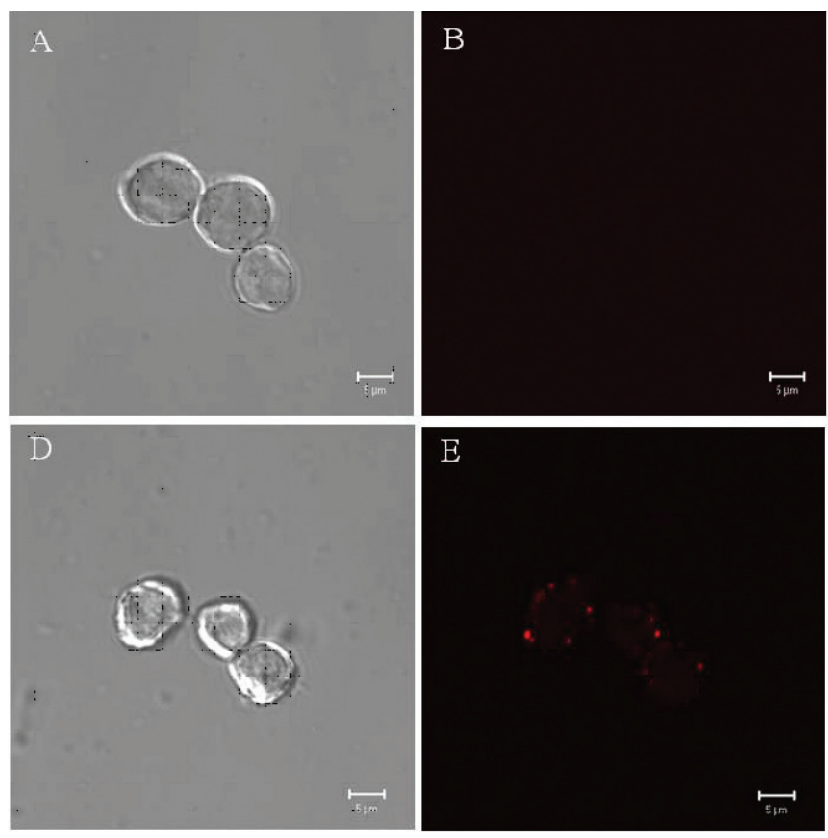
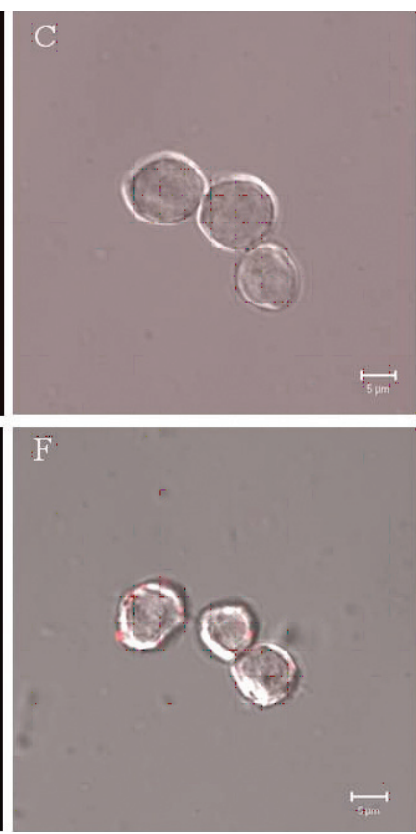

Fig. 3. Cellular location detected by confocal microscope after treatment of MNP@SiO ${ }_{2}$. PBS treated control shows no signal of nanoparticles (A-C). However, 50 nm treatment of MNP@SiO ${ }_{2}(50$ $\mu \mathrm{g} / \mathrm{ml}$ ) shows the cellular location of $\mathrm{MNP} @ \mathrm{SiO}_{2}$ in cytoplasm, mainly around cell membrane (D-F). $(A, D)$ Live image, $(B, E)$ Confocal image, (C, F) Merged image at 24 $\mathrm{h}$ after treatment, $\times 800$ magnification. 

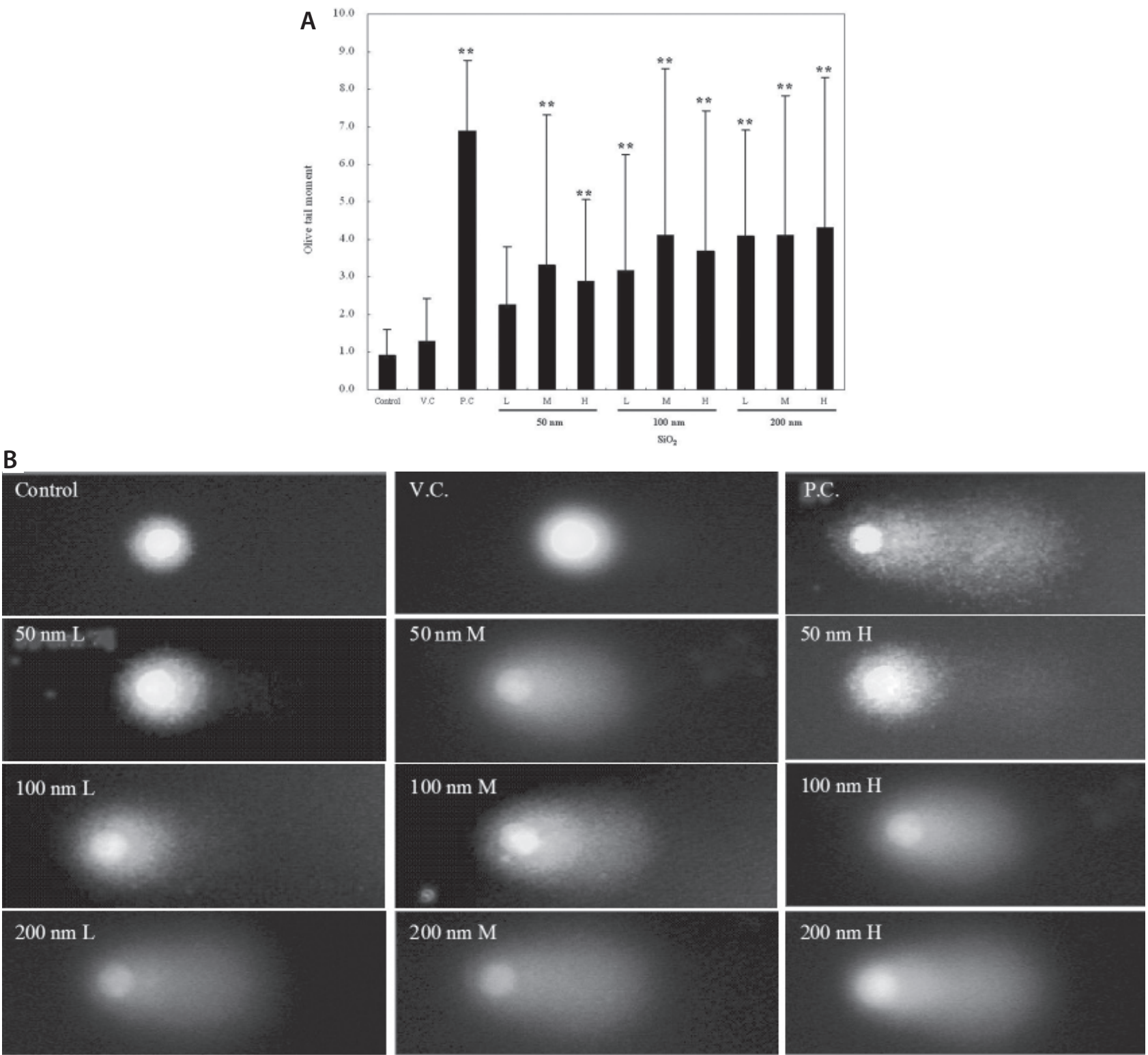

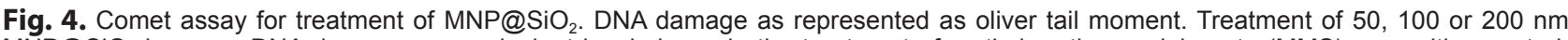
MNP@SiO ${ }_{2}$ increase DNA damage, as equivalent level shown in the treatment of methyl methanesulphonate (MMS) as positive control. Representative figures from control and 50, 100 or $200 \mathrm{~nm} \mathrm{MNP@SiO}$ treatment groups; $\mathrm{L}, \mathrm{M}$ and $\mathrm{H}$ mean low (31.25 $\mu \mathrm{g} / \mathrm{ml})$, middle (62.5

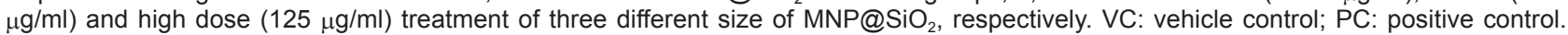
${ }_{* \star}^{*}$ Significantly different from vehicle control $(p<0.01)$.

nucleus, causing cell mortality in a dose-dependent manner (Porter et al., 2007). Further studies will be warranted in this possibility with specific method.

Many of nanoparticles assessed were found to cause genotoxic responses (Singh et al., 2009). In fact, titanium dioxide could induce oxidative damage to human bronchial epithelial cells (Gurr et al., 2005) and zinc oxide could enhance genotoxicity in irradiated circumstance (Dufour et al., 2006). Genotoxicity of nanoparticles in cells can be assessed by several methods for determination of gene mutations, cytogenetic assessment of chromosome damage and detection of micronuclei and evaluating DNA strand breaks (Hillegass et al., 2010). Among these, Comet assay was microgel electrophoresis method to find DNA damage directly in cellular level (McNamee et al., 2000). In this study, MNP@SiO ${ }_{2}$ treatment induced DNA damage detected by Comet assay. Interestingly, we found that there were little variation of oliver tail moment in control and positive control value, in contrast with large

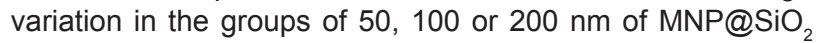
treatment. It seems that there may be different cellular susceptibility and variable level of cellular damage in treated cells, irrespective of size.

Even some nanoparticles (including metal nanoparticles, metal-oxide nanoparticles, quantum dots, fullerenes) were 
found to cause genotoxic responses, such as chromosomal fragmentation, DNA strand breakages, point mutations, it is difficult to draw conclusions that nanoparticles might promote genotoxicity, largely due to physicochemical features and study design (Singh et al., 2009). Actually, the $\mathrm{MNP} @ \mathrm{SiO}_{2}$ did not induce any significant chromosome aberrations (Kim et al., 2006). However, our results clearly suggest that they might induce DNA damage. And recent study reported that silica nanoparticles induce global genomic hypomethylation (Gong et al., 2010). In this time, it will be needed to do more research for assessing toxicity of silica nanoparticles detected by conventional or advanced method(s) in specific condition.

Taken together, treatment of $\mathrm{MNP@SiO}$ induced cytotoxicity and they were located in cells within a short time, and they might induce DNA damage in L5178Y cell, associated with cellular location within short time after treatment.

\section{ACKNOWLEDGMENTS}

This research was supported by a research grant from Korea Food and Drug Administration.

\section{REFERENCES}

Aillon, K. L., Xie, Y., El-Gendy, N., Berkland, C. J. and Forrest, M. L. (2009) Effects of nanomaterial physicochemical properties on in vivo toxicity. Adv. Drug Deliv. Rev. 61, 457-466.

Akhtar, M. J., Ahamed, M., Kumar, S., Siddiqui, H., Patil, G., Ashquin, M. and Ahmad, I. (2010) Nanotoxicity of pure silica mediated through oxidant generation rather than glutathione depletion in human lung epithelial cells. Toxicology 276, 95-102.

Dufour, E. K., Kumaravel, T., Nohynek, G. J., Kirkland, D. and Toutain, H. (2006) Clastogenicity, photo-clastogenicity or pseudo-photoclastogenicity: Genotoxic effects of zinc oxide in the dark, in pre-irradiated or simultaneously irradiated Chinese hamster ovary cells. Mutat. Res. 607, 215-224.

Gong, C., Tao, G., Yang, L., Liu, J., Liu, Q. and Zhuang, Z. (2010) $\mathrm{SiO}(2)$ nanoparticles induce global genomic hypomethylation in HaCaT cells. Biochem. Biophys. Res. Commun. 397, 397-400.

Gurr, J. R., Wang, A. S., Chen, C. H. and Jan, K. Y. (2005) Ultrafine titanium dioxide particles in the absence of photoactivation can induce oxidative damage to human bronchial epithelial cells. Toxicology 213, 66-73.

Hamilton, R. F. Jr., Thakur, S. A. and Holian, A. (2008) Silica binding and toxicity in alveolar macrophages. Free Radic. Biol. Med. 44, 1246-1258.

Hillegass, J. M., Shukla, A., Lathrop, S. A., MacPherson, M. B., Fukagawa, N. K. and Mossman, B. T. (2010) Assessing nanotoxicity in cells in vitro. Wiley Interdiscip. Rev. Nanomed. Nanobiotechnol. 2, 219-231.

Holsapple, M. P. and Lehman-McKeeman, L. D. (2005) Forum series: research strategies for safety evaluation of nanomaterials. Toxicol. Sci. 87, 315.

Jin, Y., Kannan, S., Wu, M. and Zhao, J. X. (2007) Toxicity of luminescent silica nanoparticles to living cells. Chem. Res. Toxicol. 20,
1126-1133.

Kim, J. S., Yoon, T. J., Yu, K. N., Kim, B. G., Park, S. J., Kim, H. W., Lee, K. H., Park, S. B., Lee, J. K. and Cho, M. H. (2006) Toxicity and tissue distribution of magnetic nanoparticles in mice. Toxicol. Sci. 89, 338-347.

McNamee, J. P., McLean, J. R., Ferrarotto, C. L. and Bellier, P. V. (2000) Comet assay: rapid processing of multiple samples. Mutat. Res. 466, 63-69.

Nabeshi, H., Yoshikawa, T., Matsuyama, K., Nakazato, Y., Arimori, A., Isobe, M., Tochigi, S., Kondoh, S., Hirai, T., Akase, T., Yamashita, T., Yamashita, K., Yoshida, T., Nagano, K., Abe, Y., Yoshioka, Y., Kamada, H., Imazawa, T., Itoh, N., Tsunoda, S. and Tsutsumi, Y. (2010) Size-dependent cytotoxic effects of amorphous silica nanoparticles on Langerhans cells. Pharmazie 65, 199-201.

Nel, A., Xia, T., Madler, L. and Li, N. (2006) Toxic potential of materials at the nanolevel. Science 311, 622-627.

Nishimori, H., Kondoh, M., Isoda, K., Tsunoda, S., Tsutsumi, Y. and Yagi, K. (2009) Silica nanoparticles as hepatotoxicants. Eur. J. Pharm. Biopharm. 72, 496-501.

Oberdorster, G., Ferin, J. and Lehnert, B. E. (1994) Correlation between particle size, in vivo particle persistence, and lung injury. Environ. Health Perspect 102(Suppl 5), 173-179.

Oberdorster, G., Oberdorster, E. and Oberdorster, J. (2005) Nanotoxicology: an emerging discipline evolving from studies of ultrafine particles. Environ. Health Perspect 113, 823-839.

Papageorgiou, I., Brown, C., Schins, R., Singh, S., Newson, R., Davis, S., Fisher, J., Ingham, E. and Case, C. P. (2007) The effect of nano- and micron-sized particles of cobalt-chromium alloy on human fibroblasts in vitro. Biomaterials 28, 2946-2958.

Porter, A. E., Gass, M., Muller, K., Skepper, J. N., Midgley, P. A. and Welland, M. (2007) Direct imaging of single-walled carbon nanotubes in cells. Nature Nanotechnology 2, 713-717.

Singh, N., Manshian, B., Jenkins, G. J., Griffiths, S. M., Williams, P. M., Maffeis, T. G., Wright, C. J. and Doak, S. H. (2009) NanoGenotoxicology: the DNA damaging potential of engineered nanomaterials. Biomaterials 30, 3891-3914.

Sohaebuddin, S. K., Thevenot, P. T., Baker, D., Eaton, J. W. and Tang, L. (2010) Nanomaterial cytotoxicity is composition, size, and cell type dependent. Part. Fibre. Toxicol. 7, 22.

Thomas, K., Aguar, P., Kawasaki, H., Morris, J., Nakanishi, J. and Savage, N. (2006) Research strategies for safety evaluation of nanomaterials, part VIII: International efforts to develop risk-based safety evaluations for nanomaterials. Toxicol. Sci 92, 23-32.

Thomas, K. and Sayre, P. (2005) Research strategies for safety evaluation of nanomaterials, Part I: evaluating the human health implications of exposure to nanoscale materials. Toxicol. Sci. 87, 316-321.

Yang, X., Liu, J., He, H., Zhou, L., Gong, C., Wang, X., Yang, L., Yuan, J., Huang, H., He, L., Zhang, B. and Zhuang, Z. (2010) SiO2 nanoparticles induce cytotoxicity and protein expression alteration in HaCaT cells. Part. Fibre. Toxicol. 7, 1.

Ye, Y., Liu, J., Xu, J., Sun, L., Chen, M. and Lan, M. (2010) Nano-SiO2 induces apoptosis via activation of $\mathrm{p} 53$ and Bax mediated by oxidative stress in human hepatic cell line. Toxicol. In Vitro 24, 751-758.

Yoon, T. J., Kim, J. S., Kim, B. G., Yu, K. N., Cho, M. H. and Lee, J. K. (2005) Multifunctional nanoparticles possessing a "magnetic motor effect" for drug or gene delivery. Angew. Chem. Int. Ed. Engl. 44, 1068-1071.

Yoon, T. J., Yu, K. N., Kim, E., Kim, J. S., Kim, B. G., Yun, S. H., Sohn, B. H., Cho, M. H., Lee, J. K. and Park, S. B. (2006) Specific targeting, cell sorting, and bioimaging with smart magnetic silica coreshell nanomaterials. Small 2, 209-215. 